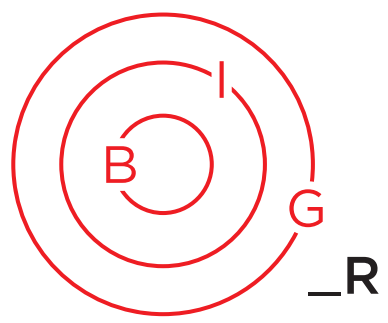

ARTICLE SPECIAL SECTION

\title{
Identity, Religion and Difference in the Borderland District of Poonch, Jammu and Kashmir
}

\author{
Malvika Sharma *
}

This article (part of a special section on South Asian border studies) is an exploration of a multi-religious ethnic group in the borderland district of Poonch in Jammu and Kashmir, India. The work focuses on the Pahari ethnicity and looks at how prominent religious identities within this group have been continuously aligning themselves along religious lines in the post-partition era. Partition of the Indian subcontinent in 1947 acted as a major disruption in the construction of identities. The evolution of national and ethnic identities went hand in hand with the evolution of religious identities, with the latter being more pronounced than the former. Such a fixation along religious lines in the socio-cultural and political sphere led to changes in everyday inter-community relations. Through oral histories and other accounts, this ethnography understands the new set of interactions that emerged in Poonch which have been shaping identities, while also analysing identity construction and its impact on the social organisation of space and neighbourhoods in general in the post-partition era.

Key Words: Borderland, Border, Boundaries, Community, Communalism, Difference, Ethnicity, Identity, Inter-community interaction, Nation, Nation-State, Othering, Religion

\section{Introduction}

In August 1947, the Indian subcontinent witnessed one of the bloodiest partitions along religious-lines in recent history, which led to the territorial division of the subcontinent into the nation-states of India and Pakistan. Though the event took place in August, it struck Jammu and Kashmir (then a princely state) in October 1947, two months after it hit the provinces of Punjab and Bengal. Poonch, the borderland that is the focus of this study, existed as an erstwhile fiefdom/principality in the princely state when the partition bisected it into two halves, each now existing as a borderland along two sides of the same boundary in Jammu and Kashmir. This work explores the role that the 1947 partition played in transforming both the socio-cultural and political nature of the 'space' of the fiefdom of Poonch in the pre-partition era and the hostile borderland that it has become in the post-partition period, thereby understanding partition as a rupture that stands in between the being and becoming of this borderland. ${ }^{1}$

The 1947 partition and the events that unfolded as a result of it in Jammu and Kashmir, particularly in the fiefdom of Poonch, form a major line of inquiry in this research that further informs the change in interactions between communities in the post-partition scenario. In fact, partition acts as a base-year/event for this research as any kind of religious-reassertion explored in this work has its origins in the turn of events in 1947 when partition

\footnotetext{
* Malvika Sharma, PhD Candidate, Sociology, Centre for the Study of Social Systems, School of Social Sciences, Jawaharlal Nehru University, New Delhi, India. Email: malvikasharma58@gmail.com
} 
first occurred. Due to a lack of secondary material on this topic, this research relies heavily on first-hand accounts, oral-histories, narratives, and memory as tools of research. My on-going work in the borderland of Poonch is perhaps first of its kind in the sociological and social-anthropological study of this region. Most of the narratives I collected, as shall be shown below, are deeply connected with the events of 1947. The narratives of contemporary life are intertwined with narratives of partition and have, in fact, shaped the social/political life in Poonch by transforming it into a borderland. Thus, the establishment of the borderland of Poonch lies in the unbecoming of the ethno-scape it was, with this transformation resting heavily on the 1947 partition as an event/a disruption/a rupture in the social-political and cultural history of this region. ${ }^{2}$

Poonch emerged as a borderland in the post-1947 era where a tragic set of events divided the territory of Poonch that existed as a jagir/fiefdom/principality under the monarchy of the princely state of Jammu and Kashmir into two halves. The infamous Pukhtoon-tribal-raid aimed at capturing the city of Srinagar, ${ }^{3}$ struck Poonch in late October 1947, and unleased targeted carnage and violence that continued for months thereafter. The first Indo-Pak war of 1947-48 lasted for more than a year and ended, due to UN-intervention, in the declaration of a ceasefire where both the states agreed to a ceasefire line (now known as the line-of-control or the LoC) that was laid across the points held as of January 1, 1949 by troops of both the nation-states. ${ }^{4}$ It was this cease-fire line formed at the culmination of the first Indo-Pak war that divided the fiefdom of Poonch into two parts, with one part lying on the side of the line in India and the other part in what came to be known as Azad Jammu and Kashmir, contested by India as a disputed territory. ${ }^{5}$

Borderlands are lived-habitable spaces where the implications of there being a strategic-cartographical boundary running through them cannot overlook the processes and inter-personal exchanges that shape the communities who inhabit these hostile contours. Once these regions along boundaries such as LoC are recognized as also regions with life, then the narrative changes, something that has been referred to in the works of Paasi (1998), Newman (2004), and Gellner (2013). Hence, diversified works in the social sciences take up where conventional political science and international-relations leave off. Sociology and social anthropology study borders as borderlands wherein they take into account the lived experiences of communities that inhabit them. Following these lines, this paper looks at the inter-communitarian interactions (between Muslims and non-Muslims largely) that constitute these lived habitable spaces thereby making borderlands living zones, much more than their perception of being cartographical-zones dividing sovereign nation-states. Poonch, as a borderland, has been made and unmade through various changes that the communities that constitute Poonch as Poonchies (the people of Poonch) have witnessed since 1947. These evolutions involve key changes to the interactions between communities. Another important point here is to see how borderlands in the north-western periphery along the LoC in Jammu and Kashmir have been least explored sociologically and anthropologically. A few of the good ethnographic accounts in the scholarship around this zone have come from Ladakh and Kargil, in an undivided state of Jammu and Kashmir, before its division into two union territories of Ladakh and, Jammu and Kashmir respectively after the recent abrogation of special status under article 370 in the Indian constitution on August 5, 2019 (Aggarwal 2004; Gupta 2013). The reasons for the lack of good sociological and anthropological studies are many, key among them are: these borderlands being one of the most hostile and violent zones of high risk; security and surveillance with issues of accessibility and mobility; and the marginal peripheral ethnicities that reside here, which are different from dominant identities of Dogra, Kashmiri and Ladakhi. 6

The Pahari-Poonchies are a community of ethnic relevance. Belonging to Pahari ethnicity, they are a linguistic group speaking the Pahari-pothowari dialect, 7 residing in a common territory with shared values and cultures (Oommen 1997; Smith 1986). They are a multi-religious ethnic group with a predominantly Muslim population, and with a substantial minority Hindu and Sikh presence. ${ }^{8}$ Besides shared ethnicity, the community as a Poonchi-Pahari community has a shared past that traversed the turbulent pre- and post-partition eras. All three communities bore the brunt of the post-partition carnage including the other ethnicities that also reside in the region such as Koshur and Gujjars and Bakerwals. However, the violence played a major role in changing the demographic composition of the area - as will be elaborated in the following sections. The tribal-raid and the partition-violence in 1947 onwards did act as a major disruption in the ethno-history of the Poonchies, where this disruption had the potential to unleash waves leading to assertive religious identities threatening the mutually shared ethnic-ties and bonds.

The drift in the intra-ethnic-ties however did not occur abruptly. The partition led division of Poonch acted as a disruption that triggered responses which played a major role in identity building based on religious affiliations in line with the larger nation-state identity constructions in India, Pakistan and in Kashmir. This paper brings into focus the transformed identities where identities became closed, aligning more along religious lines and thus threatening inter-community interactions within an ethnic-group. From changed neighbourhoods to changed cultural exchanges, identities have been more expressive along religious lines, bringing to a social-anthropologist a new set of readings which constructs ethnicity on a hostile ground where religious identity construction seems to threaten the ethnic bonds of solidarity. Therefore the questions that this paper explores are: Does the alignment of identities within an ethnic-group render 
shared ethnicity a myth? How do the interactions in a multi-religious ethnic-group change with assertive religious identities living with the memory of a violent partition? What does this tell us about the nature of multireligious-ethnicity, plurality and co-existence? Shail Mayaram (1997) raised that being bi-religious or multireligious has been the major mode of religious being in Asia and is distinct from being singularly religious. If so, what are the new challenges to such older forms of diversity and pluralism that can be explored while studying this particular ethnic-group? This research paper taps into these challenges emanating from an already hostile geographical space, a borderland, and puts them in the larger Asian and South-Asian perspective of belonging to a community where identities are driven by religion within a nation-state.

Change in spatiality and neighbourhood patterns across the religious communities in this borderland is something that this work relies upon in order to understand identities and their assertion along religious lines. The work infers how the organisation of neighbourhoods along religious lines is a two-way process. One is where religion had shaped neighbourhoods in the town of Poonch (the site of my study) in the immediate post-partition scenario, where the huge displacement and influx of minority non-Muslim population into the town of Poonch pushed out the local Muslims; and the other where newly formed neighbourhoods have come up in contemporary times, largely organised along religious lines thereby encouraging assertion through spatial construction and its use.

\section{Boundaries Generating Difference}

This borderland ethnic community is internally segmented through 'boundaries' (social, cultural, and political) that have escalated the drift between the primary religious identities, that is, the Muslims, the Sikhs, the Hindus, and the growing population of Christians in Poonch. Boundaries generating difference here have been studied by categorizing the interactions between these religious communities as those between the Muslims and the non-Muslims largely. Michele Lamont's (2002) work on symbolic and social boundaries inspires an understanding of these boundaries that have been responsible for categorization of identities into separate units within the community. Lamont's differentiation of symbolic and social boundaries is such that he calls symbolic boundaries 'intersubjective conceptual boundaries that precede the manifestation of social boundaries' (Lamont \& Molnar 2002, 169). Before social boundaries generate evident social differences like inequality and hierarchy, which further translate into an identifiable pattern of social exclusion, it is the invisible abstract presence of symbolic boundaries that is effectively at play causing psychological difference and othering (Lamont \& Molnar 2002). The subjective individualistic and mental presence of symbolic boundaries have the ability to segregate individuals, however, it is these same boundaries that also organise individuals into groups based on various metrics of commonness, we-feeling, and compatibility. This associational and dissociational trait of symbolic boundaries makes them an interesting study for mapping exclusion and inclusion patterns, how groups in a community segregate or come together, and the forces that lead to such fluctuating changes. Lamont (2002) puts it wonderfully when he says, "How do individuals think of themselves as equivalent and similar to, or compatible with others, and how do they perform their differences and similarities in day to day lives?" Lamont's work on boundaries is an interesting prism of looking at community-relations in Poonch and seeing how boundaries work in social relationships as elaborated through empirical findings in this work ahead.

Coming to an understanding of ethnicity and religious identities, a review of Harjot Oberoi's construction of religious boundaries is useful for an understanding of conceptual categories like culture, religion, and diversity in this work. This is further substantiated by reading Oberoi's (1994) understanding of religious identities along with Smith's (1986) ethnic and national identities, Varshney's (2001) ethnicity and inter-ethnic engagement, and Nandy's (2020) understanding of religion as faith-systems.

Ashutosh Varshney's understanding of ethnic identities in a way has informed an understanding of ethnic-identities present in this borderland district. His engagement with the informal and formal networks in a community, where he differentiates the everyday informal quotidian networks between families, individuals, and neighbourhoods from the formal civil ties that are generated through formal institutions like police, bureaucracy, and civil societies is vivid. After reading through primordial, perennial, and modern constructs of nation and ethnicity (Smith 1986), Varshney's understanding of ethnicity provides fresh insight into understanding the every-day lived ethnic-life such as in the borderland of Poonch. He calls inter- and intra-ethnic ties within a community or between two or more communities 'networks of engagement', and adds that it is upon these networks of engagement that vulnerability of an ethnic group to ethnic-conflict depends (Varshney 2001). These networks of engagement decide how integrated and disintegrated a community is on ethnic-lines. According to him, formal associations play a larger role in the integration of a community, because formal associations are regulated by institutions with power unlike the quotidian associations that are successful in integrating neighbourhoods and smaller regional affiliations. But in the times of a threat it is the formal civic-ties regulated by state backed mechanizations that defer chances of a conflict and hence negate the chances of larger ethnic-violence taking place. Varshney's take on ethnic-conflict, everyday interaction, violence, riots, and pogroms, and how they all differ from each other in a way informs communal understanding of religious diverse ethnic community of Poonch as elaborated below. 


\section{Displacement Led Migration: Understanding the Transformed-Neighbourhoods}

Before understanding the shift in identities, and looking at what is causing identities to perpetually organise themselves on religious-lines in an otherwise multi-religious Pahari community of Poonch, this paper would like to first discuss how the post-partition turn of events acted as a severe disruption, changing the spatial demographic organisation of the region, especially in the town area. My ongoing fieldwork in Poonch gave me an opportunity to interact with four survivors of the October 1947 carnage, all of them nonagenarian. Their detailed first-hand accounts are a subject matter of a separate paper and demand an exclusive piece on their oral-narratives, however the narratives collected cite incidents that matched each other so well, hence validating the events that took place in 1947-48.9 These narratives also helped in locating the prime source of spatial-reorganisation based on religious identity affiliation. Before this, when I started to map the town ${ }^{10}$ and understand the construction of various neighbourhoods, it did become clear that most of the peripheral spaces in the town are largely occupied by Muslim households, with Sikhs and Hindus being located towards the centre and the core. The reasons for this are both historical and rooted in contemporary pattern of migration in and out of the town.

I started to map the town quantitatively, having decided to take fifty respondents from each community, that is, Muslims, Sikhs, and Hindus based on random sampling. Having done so, I did not get satisfactory results that might have been the required representational sample of the town. There were two reasons for this; one, because in a random sampling in every household chosen, the probability of finding people in the age bracket above sixty years was bleak (as this was the age-group that I was particularly interested in as their narrations were crucial in grasping the social-history of the region) and two, the demarcation between neighbourhoods was not always sharp particularly in the semi-peripheries where neighbourhoods were with a mixed population. Moreover the entire exercise seemed like an institutional survey that could not satisfy my desire to study this community through narratives. I purposely chose to snowball through my contacts and acquaintances and visited people across religions who fell in the right age-group and who could speak about the events in fifties and sixties in an immediate post-partition phase. It is here where I obtained the narratives of four men above eighty years of age who narrated for me the events dating as far back as the pre-partition past of Poonch. Also, when I started triangulating, weaving one method into another, I realised this community (please see that my site of ethnography is the town-area primarily) could only be understood once I stopped trying to find the slots for the number of respondents. I needed to instead find people who could shine light on the social history, before taking into account views of the young strata. As such, memory and oral-narratives formed the key methods that shaped my study. I realised only when I use memory as tool and studied the memory of both the space and the people along with the oral narratives that I have been fortunate to collect would I be able to deconstruct Poonch and understand its decadal transformation. It was thus that the life-histories of a few octogenarian and nonagenarian men helped me understand how Poonch changed in spatiality and demographics.

I begin my analysis with a discussion of the narratives provided by these men (the details of their narrations with a brief account on their life-histories have been included in detail in my work (2020) on Sikhs in Poonch). All four men that I approached were Sikhs and them being Sikhs was not a targeted choice but a coincidental one that made me look at the town in concentric circles rather than a space that is to be mapped through sampling. ${ }^{11}$ Why circles? Because these narratives explained how the events of 1947-48 turned the Poonch town into a camp, where people of only a particular religious affiliation could enter, barring others who belonged to a different religion. The narratives, as collected, weave the story that goes like this:

'The tribals reached Muzaffarabad somewhere around October 22 to 24, 1947. They took the RawalakoteMuzaffarabad route. At Muzaffarabad, as they were waiting for the final orders to attack Srinagar through Baramulla, as there was a delay in the orders from their chiefs, they exploited the opportunity and plundered the nearby regions. The areas falling in the fiefdom of Poonch such as tehsil(sub-district centre of administration and governance) Bagh, Sudhnoti, Haveli, Mehndhar etc had multireligious inhabitations and in fact most of the villages had substantial Hindu-Sikh families. The raid and plunder had already taken a communal colour and so the minority Hindus and Sikhs who were around $4 \%$ of the total population of Poonch were their main targets. The minority Sikhs and Hindus were thus driven out of the area that later fell on the other side of the LoC in Pakistan Occupied Kashmir. One of the tehsils of Poonch, tehsil Haveli (that constitute the present day district headquarter) was a well inhabited town with the seat of power residing within the town inside the well-guarded Poonch-Fort, from where the Raja of Poonch fiefdom exercised his suzerainty.

Two tehsils of the fiefdom that is, tehsil Bagh and tehsil Sudhnoti fell completely, and half of the territory of tehsil Haveli and a major part of tehsil Mehndhar were taken over by the raiders as well. It is only the remaining portion of the erstwhile tehsils Haveli and Mehndhar that remained on the Indian side at the time of ceasefire. As majority of the fiefdom fell, the fief-headquarters that is Haveli (the present day Poonch town, and the site of my study) became the only place of refuge for those who ran for their lives from the areas of those tehsils that fell. Sardar Kirpal Singh Sudan, Sardar Tara Singh Sudan, Sardar Dalip Singh all of them narrated this is how the present day Poonch town turned into a refugee-camp overnight, and remained so for years to come up to 1952 when the policies of refugee rehabilitation and resettlement gathered pace. 
The impact of this communal carnage was such that all the minorities from across the fiefdom took refuge in the town. The kafilas kept pouring in, some even arrived deep in the winter of December and January, fleeing their homes, leaving everything behind. From a town with a mixed population, Haveli headquarters turned into a town sheltering the last Hindu-Sikh alive across the entire region of Poonch principality. The results of these sudden turn of events were obvious: as the town area turned into a safe-haven for the minority-Sikhs and Hindus, the Muslims who resided in the town were pushed out in revenge for the wrongs that the minorities had been facing outside the town. Hence, the town lost its Muslim population completely, and it is in this context that we need to understand the present day spatial- organization in the town.' (narratives collected from the field by the author during various phases of her fieldwork conducted through 2018-2020).

It is this spatial reorganization and, its evolution and transformation over the decades since the communal-carnage led displacement and migration in 1947-48, that plays a major role in understanding the interactions between communities that further shape the neighbourhoods that exist today [Figure 1].

\section{Spatial Reification and Migratory Patterns in Poonch: The Rise of New-Neighbourhoods}

The demographic-imbalance caused by the communal carnage of 1947-48 has had its repercussions on how the neighbourhoods were constructed in the Poonch town that fell on the Indian-side post-cease-fire line demarcation of territories. In the initial phases of my fieldwork I did come across the neighbourhoods being organised on communitarian basis. Religion was the major tool that formed and organised neighbourhoods. However, it was the above mentioned narratives of post-partition that explained why a particular community was situated heavily on the peripheries and the others towards the core.

As the town sheltered the battered Hindus and Sikhs, all the Muslims had to leave as most of the non-Muslim victims occupied the ghostly homes left behind by the Muslims. With the UN-intervention and the ceasefire-line, the tensions fizzled out and the administrative machinery gathered pace after 1950. Various relief, rehabilitation, and resettlement programmes were launched catering to the needs of the displaced who, by then, were inducted into the new category of 'refugee'. Although, they had been internally-displaced as they arrived from one part

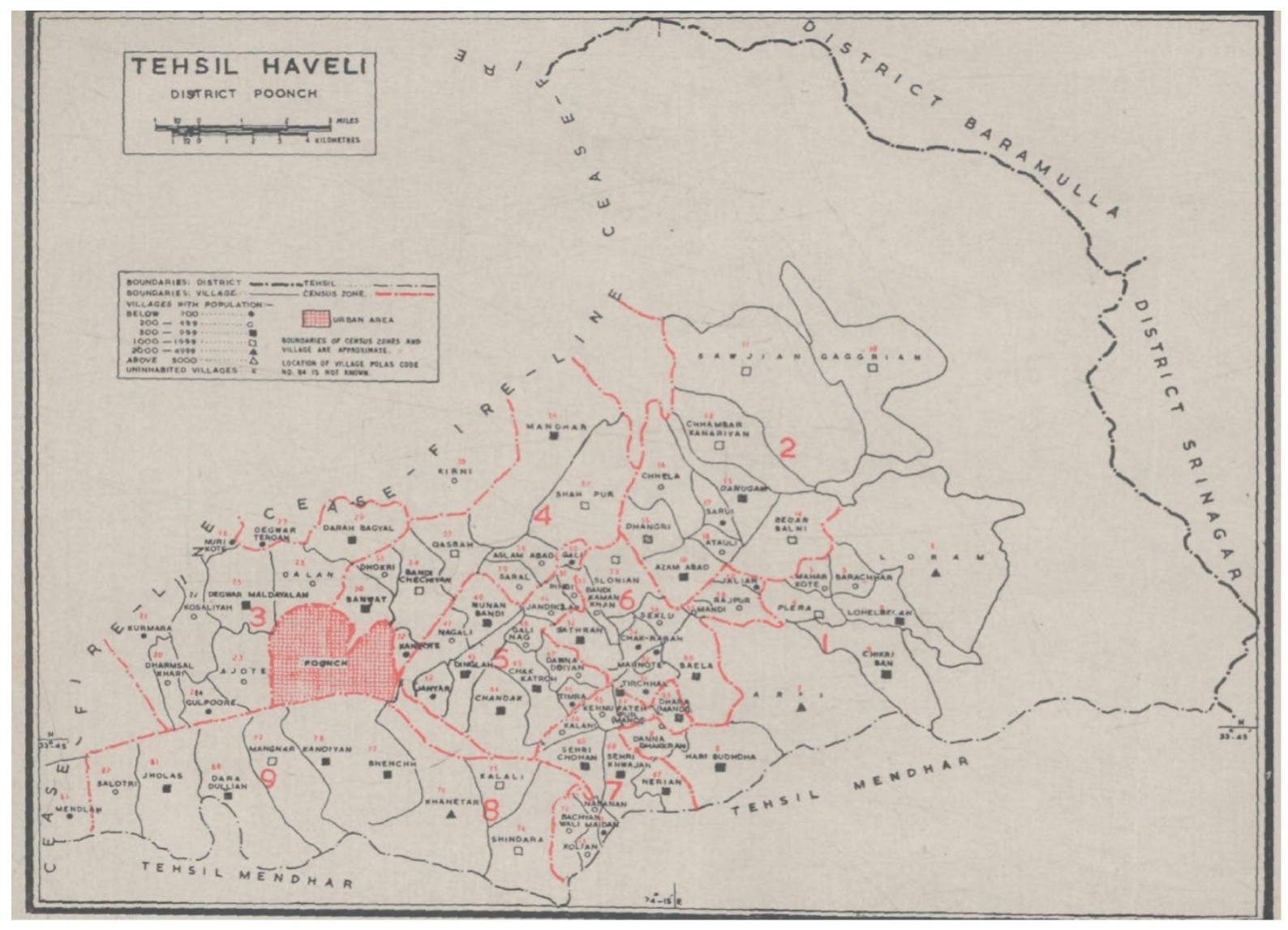

Figure 1. Map of Tehsil-Haveli, in district Poonch, showing the Poonch-town and the cease-fire line passing through it North-western side. The map also show the frontier villages of Jhullas (Jholas) and Khari-Karmara (refered to as Dharamsal Khari-Kurmara in the map) mentioned in this work, at its extreme western front. Source: Census 1961, 373. http://Isi.gov. in:8081/jspui/bitstream/123456789/5865/1/24735_1961_POO.pdf 
of the erstwhile Poonch-fief into another, but because of the UN-intervention and the ceasefire-line in January 1949 they now belonged to the Indian part of Poonch as 'Refugees', as the other part of Poonch on the other side of the LoC by then was a contested territory for India belonging to Azad Jammu and Kashmir. The new occupants and settlers in the town (the minority natives besides the refugees who were also natives of Poonch but from a few-kilometre across the line) formed the vast majority occupying almost all the space in the town until 1952. These refugees are essentially the 'Pakistan Occupied Jammu and Kashmir Dis-placed Persons', the category that exist in papers of the state. They are known as refugees locally because of the familiarity of the term in the local languages along these borderlands. However, the official state category for them is 'displaced-persons' (Sharma 2020; 2021). With the rehabilitation process, these refugees were allotted lands with a scale of 48 acres given to each family head based on a notary Alpha/ Alaf form which had the name of the head who was allotted the land.

The land however was not allotted equally to each refugee family because of the obvious loopholes in the administrative and disbursement mechanisms. As the people on the ground add that the land was allotted based on who had the agency and the power to reach the gates of the disbursement mechanism first. Most of the refugees added that the elderly in their households were ignorant and could not complete the required paperwork on time. Thus those who were swift enough have around 48 acres today, and others have no more than 20 acres. To note here also is the point that these lands allotted were located both within the town area and outside in the neighbouring villages as well. The suffocating town-space thus had a breather when refugees and especially the native minorities who also had to take refuge in the town began spreading in the villages around the town.

With the rehabilitation of the non-Muslim minority refugees, the reinstatement of the Muslims who had to flee from the town and the neighbouring villages also took place. However not all Muslims who chose to come back were reinstated in their original property as some of their property was considered to be evacuee property and was allotted or taken over by the Hindus and Sikh refugees between 1947 and 1952. Thus, the only lands left for them were in the periphery of the town or in the villages where such a population explosion had not happened.12 Thus the present day spatial occupation scenario has its roots in the post-1947 turn of events, where the periphery was occupied by the Muslims who resettled in and around Poonch post the rehabilitation and administrative changes after the first ceasefire-agreement between India and Pakistan.

Adding to such origins of rebuilding a town-space after the partition-disruption are the migration-patterns that have been a major force behind organisation of neighbourhoods in the town space. Understanding these patterns that are more active in the contemporary times than in the past few decades is the core concern of my present phase of research, but suffice it to say here is the peculiar process through which Poonchies have been migrating to larger cities. Particularly the migration to Jammu is an outmigration trend that is seen more among the minority Pahari Hindus and Sikhs with that of Muslims now on the rise. A layer of reasons exist but to write that I have coherently traced these migratory changes would be quite insufficient at this point of time. Although, as of now based on the ground-narratives and observation, I can deduce that the migration is hefty on the side of the Hindus and the Sikhs. The following section on identities shall explain how one cannot anymore write of Hindus and Sikhs as a non-Muslim minority mix community that suffered together, as one ethnicity until 1950s. The Hindu and Sikh identities have bifurcated and solidified as much as a Muslim identity in the past few decades. Bifurcated because the minority Pahari Hindus and Sikhs of Poonch had a culture of mix-families, where two brothers in the same family lived with two different faiths, one a Sikh and the other a Hindu. Hindu and Sikh families had this shared faith system within the same family, but over the years with the hardening of identities, the same brothers today have much less religious exchange and have gradually begun asserting a Hindu and a Sikh identity respectively. This has been explored in great details in my work on Sikhs (Sharma 2020).

The heavy Hindu-Sikh migration (who constituted a mere 4-6\% of the total population of Poonch) to cities like Jammu and elsewhere has led to the selling of the lands to Muslims. Over the last decade, Muslims from around the villages have been settling in the town in large numbers. One wave of migration in nineties, between 1990-1998 affected Muslims, Hindus, and Sikhs equally, where Hindus and Sikhs out-migrated to cities like Jammu, and Muslims in-migrated into the town of Poonch. This migration was driven by the chaotic times during which terrorism was at its peak. Migration within and outside Poonch has been taking place due to three main reasons: Terrorism, the survival necessities of being a borderlander, and the obvious socio-economic push and pull factors. Terrorism during the 1990s affected all the communities belonging to different religious and ethnicities in this borderland.

The Hindus and Sikhs who have migrated to Jammu usually have one reason in common which is that Poonch is a border ilaqa (region), with majority Muslim population. Besides the territorial backwardness, the threat that one day if situation turns sore again then there is no chance of survival being a meagre $6 \%$ minority (hinting at the scars of communal carnage of 1947 being still ripe and the denial of such an event occurring again is less likely to be heard among the minorities today) is also a driving force behind such a migration. Muslims who have suffered at the hands of terrorists in the villages had this opportunity as the new buyers and town settlers when the minority Hindus and Sikhs were/are selling off their lands. Hence, the periphery of the town gradually became 
a majority Muslim settlement with dispersed Hindus and Sikh households. The following narratives from the field shall shine sufficient light on how these migratory patterns among all the three main communities changed interactions and widened the communal gap between them.

Poonchies, from all ethnicities have formed colonies in the peripheral regions of the Jammu city (the next big city outside the town) and they look out for land that lies in the vicinity of the lands already purchased by another Poonchi family, thus catering to the concept of a colony. Having a land or a house in Jammu is considered an asset, which has connotations that go beyond the economics of buying a property and hints at the prime reason for migration particularly among the non-Muslims here (which is that they are looking for safe-havens or a place they can look up to in times of urgency). The fears behind this urgency are both external (violence and other cons of living at a borderland, especially a violent zone of conflict like this one) and internal (intra-ethnic differences which can take up a communal form).

\section{Shift in Identities: Narratives from the ground}

The interactions in this community are not the same everywhere. The dynamics are so layered that identities often overlap and blur the boundaries, sometimes leaving no clear space to differentiate at all. On the extreme north-western side of Poonch touching the Line of Control lies village Khari-Karmara. The village is the last territory on this side of LoC in India. We find a single Hindu family living in an all Muslim dominated village, refusing to leave and migrate to the town. The frames are thus, not all hostile. Ethnic solidarities do overcome other divisive forces. Similarly, the house of Rammohan (name changed), who has two daughters and a son, resides at such a place in the Jhullas village where 6 o'clock in the evening is night and it lasts till seven in the morning. The lone Hindu house, situated at a trek of one hour on foot from the village centre of Jhullas (the last village at the border, a new road now has come up that connects habitations such as Rammohan's with the village centre), this house is the space of a hundred details. It is situated in a deep dark gorge with only a few Muslim neighbours. This land was allotted to Rammohan's ancestors when they migrated from a part of Poonch across the LoC and hence he too is a refugee, an officially displaced person in the eyes of the state. He has two adult daughters who trek daily up and down and one of them works in the village health centre as a nurse. He refuses to leave, and more than him it's his Muslim neighbours who deny him the permission to leave. They threaten to migrate along in case he did. Though for 'unfortunate times' he has built a house in the town in which he has never resided, but I wonder what more did he mean by 'unfortunate-times', when he has survived through the violent nineties along with all the major wars between India and Pakistan. More than militancy and encounters, he has ghost stories to tell and as we were taking leave of him, he guided us through a safer path which as he says has been sanitized with rituals (one can see Hindu ritualistic threads and vermin along with chadars from Peers' courtyards placed all over). It was a path meant and known earlier only to those four households, one Hindu and three Muslim with the neighbourhood having expanded in the recent years. The family of Rammohan has lived like a family with their Muslim neighbours, but with other precautionary havens built elsewhere, such as the one he owns in the town.

Pahari-Poonchies are thus also a 'plural' community, with all four main religions cohabiting as an ethnie-most of them connected through ancestral ties, kinship, culture, and traditions. Besides ethnic makers like language, traditions, and food, the Paharis of Poonch have also been reasserting their identity as a community together for reservation. Since the 1990s, the entire community has been mobilising support within the state and have organized themselves under several platforms such as the Jammu and Kashmir Pahari People's Forum. The state in 1989 forwarded a list of minorities that should be considered for the grant of scheduled tribe status. Among them, Gujjars and Bakerwals were chosen but Paharis were left out after a committee was established by the Centre for scrutinizing the list provided by the state of Jammu and Kashmir. Ever since then, their struggle for minority status has continued, ${ }^{13}$ which has also led to ethnic-conflict and other fault-lines between these two ethnicities (the Gujjars-Bakerwals and the Paharis), a topic that needs to be explored further (Chaudhary 2011). At the same time this conflict has solidified ethnic-ties and bond within the multi-religious Pahari ethnicity.

The fixation on identities has happened gradually without any explicit communal overtone. It is the fixation and multiplication of these identities in recent times that carries a threat to ethnic-unity here which had not been the case previously. The identities also do not get fixed as communal identities alone. By fixation and reified identities I mean identities that cause difference and othering, which are ultimately an anathema to ethnic-homogeneity and syncretism and plurality. The othering had led to differences that have divisive tendencies. The case of the assertive Hindu-Sikh identities within the same family with shared faith-systems quoted above and elaborated in a separate research paper, explains this (Sharma 2020). Such an intangible symbolic-cultural boundary may not directly lead to sharp polarisation, it does lead to irrevocable 'difference' that carries the potential to create new assertive identities out of a pool of diverse ones. Two incidents in the past few years from this site of ethnography hint at the dissociation between communities that has otherwise not been found in the decades after the partition carnage.

For any outsider, Poonch appears to be a flagrant multi-religious town on the very first evening of their arrival. The cacophonous loudspeakers start simultaneously from Temples, Mosques, and Gurudwaras both at the fall of the 
dusk and at the arrival of the dawn, but more than noise they are a tradition that no district administration has been able to do away with not even under the provision of controlling noise-pollution. Locals add on a lighter note that every morning and evening the loudspeakers from the three main religious sites of worship actually compete with each other as to who shall continue louder and longer. On paying a visit to a Hindu household one evening (it was one of those few non-Muslim households in an all Muslim neighbourhood in the periphery of the town), one of the female inhabitants reacted unhappily at the sound coming from a mosque in the neighbourhood. Her resentment clearly was something that was new and unfound as sounds from the mosque were one of the biggest elements of the 'sounds of religion' that fill the towns in the mornings and in the evenings. Any Poonchi, irrespective of ethnicities, who has been a part of this ethnic borderland can hardly complain over such a sound emanating from any religious place primarily because, being a Poonchi, they ought to have lived such a plural life. My astonishment was short-lived as after a few minutes into the conversation, it was revealed it was because the woman had been affiliated to the right-wing political party in the town and had served as one of its workers.

Another incident involving sounds and noises on a religious front had to do with the annual Budda Amaranth pilgrimage that the town proudly receives around the festival of Rakshabandan. The legend relates this pilgrimage with the other pilgrimage, that is, the Amarnath-Pilgrimage near Srinagar which is also one of the biggest pilgrimages of Hindus across the country. This pilgrimage in Poonch goes by the name BuddaAmarnath, or baba-chattaani (a stone shiva-linga) as compared to baba-barfani (the famous snow shiva-linga) in Srinagar. Pilgrims in large numbers arrive every year in a span of around 10 days and visit Budda-Amarnath in tehsil Mandi of district Poonch. Tehsil Mandi is located 30 kilometres from the town and is a majority Muslim tehsil with a prominently Kashmiri-population. ${ }^{14}$ On the eve of Rakshabandhan, a procession called Chadi-yatra leaves the Poonch town on foot for the Budda-Amarnath Shrine in Mandi. The procession is received wholeheartedly by the Muslim traders association at Mandi with meethasharbat (sweet drinks) marking the age old custom of fraternity and brotherhood in the district. However, in the year 2018, this tradition that stood as an ideal for religious tolerance and harmony took a wrong turn.

The narrative, as told, was that when the procession entered Mandi tehsil, a group of men started shouting slogans such as, 'Mandi main rehna hoga toh Ram naam kehna hoga, one who resides in Mandi has to bow to Lord Ram which did not align with the ethno-religious environment of the area they were passing through. With Mandi being a majority Muslim region that has welcomed this pilgrimage with open arms thereby understanding religion beyond a monolithic-identity and as an ethnogeographic category (see Harjot Oberoi's work and my work on Sikhs in Poonch), the religious plurality in Poonch was consequently scarred in the 2018 procession. Narratives from the ground have corroborated that the situation got way too out of control. Though it did not lead to a riot of any sort, it did teach Poonch and its ethno-geographic religions a lesson. The trauma of the memory of this exchange shall take years to die. One should also take into account that these communal forces are well at play under the influence of external agencies that own a communal political tone. The intra-ethnic gap and rise in tensions such as these multiply in the times when political parties with a conservative bend run the affairs of the state from a centre stage. These forces should take into consideration that communal politics will lead pockets like Poonch to a stage where it may not take long for religion as a regional ethno-geographic construct to transform into religion as a monolith, an identity that breeds difference and othering. ${ }^{15}$

I have been writing most of this paper in the post-370 context in Poonch, where various regions of the erstwhile state have been put under restrictions of all sorts for the past three months. I was in the field when the decision was declared on August 5, 2019, abrogating article-370 and along with it ending the special status given to Jammu and Kashmir under the Indian constitution. A few days into the communication-blockade where we had no connectivity at all with the world outside Poonch, I met this elderly Muslim Gujjar who worked as a land-labourer on a field owned by a Hindu. He was visiting his employer's household when I happen to be there too. A labourer by occupation, he said something that, in a way, highlights the nature of ethnic and religious tolerance among communities in this borderland.. He said, 'bas bhaichara bana rehna chahiye, baaki siyasi masalaat toh chalti rahegi, hum border ke rehne wale hain, sarkarrein yeh sabh badlaav laati rehti hain/ we should remain united as we have always been, for we are borderlanders and such a unity matters to us more than the politics that is bent on dividing us. It is in the nature of politics to bring changes such as the abrogation of article 370. Nothing should disrupt our unity again.'

Paul Brass (2003), in his work 'The Production of Hindu-Muslim Violence in Contemporary India', takes on Varshney's analysis that understands a riot situation as something that is reached due to the breakdown or an absence in civic-ties between and across communities. Brass states that a riot situation is reached not only due to the breakdown of inter-community civic ties but also due to 'institutions of riot' that are well established and planned riot-inducing establishments led by those with a larger political purpose in mind (such as electoral gains). While Varshney (2008) understands 'civic-ties' as the everyday 'networks of engagement' between and within communities, neighbourhoods, Brass (2003) understands riots and hence, communal violence, as 'socio-political networks' led by specialists in riot production. These specialists can operate at any level, and through his empirical findings vis-à-vis the city of Aligarh, 
Brass (2003) shows how 'specific neighbourhoods' in a city witness more violence and therefore, are more volatile because they are intentionally kept so in a way that keeps tensions simmering and the divide between religious communities grows every day. Seasoned riot specialists are always active in these localities and one of the premises that Brass uses to draw this inference is 'the changing neighbourhood patterns'. These patterns go hand in hand with local rivalries over economic resources, space, and religious hatred. Varshney also classifies neighbourhoods according to close-networks of engagements with strong civic ties, and loose-networks of engagement with weak civic ties. The chances of communal tension and hence, violence is greater in the latter. Nandy (2020) in 'The Politics of Secularism and the Recovery of Religious Tolerance' bisects religion into faith and ideology. Faith, he writes, 'means religion as a way of life, a tradition that is definitionally non-monolithic and operationally plural.' Ideology, he writes, 'means religion as a sub-national, national, cross-national identifier of populations...protecting non-religious, usually political or socio economic interests...this religion as an ideology gets identified with one or more texts, which rather than the ways of life of the believers, then become the final identifiers of the pure form of religions' (p.322).

Going by this, the changing neighbourhood patterns in the town of Poonch over the years in a post-partition context have been leading to loose networks of engagement with weak civic ties, but important here is to see that the identities have not been completely polarised. Anecdotes shared in this paper from lone Hindu-Sikh households residing in absolute harmony with their Muslim neighbours in the frontier villages outside town show this. Identities have been evolving and changing with prominent religious assertion, but a study of this borderland shows how it is the mother ethnic-identity of being a Pahari that has been binding the communities together through a simultaneous assertion for reservation and solidarities built through the collective memories of past (partition and survival as borderlanders among others).

\section{Conclusion}

Ethnicity as an identity fails to wane in the contemporary cosmopolitan world. Ethnic-solidarity existing in peripheral geographies such as in the borderland of Poonch relies on the territorial-proximity, common language as a medium of communication, shared cultural bonds, and collective histories and memories, to flourish. Communities such as Pahari-Poonchies dwell together and affiliate through shared cultures and traditions which they derive from a particular ethnic-lineage. This very nature of ethnic-solidarity has been undergoing changes with the gradual assertion of identities along multiple lines-spatiality and the construction of neighbourhoods along religious lines being one of them. This shift in the nature of identities in a post-partition context is not without the scars of the partition where the migration and displacement along religious-lines that took place during partition are living histories and memories with key influence on social-cultural life in a post-partition phase. It may take several forms, as in addition to the shift along religious lines, identities also can also start being assertive along caste, class, and gender lines. At Poonch, this gradual transformation and fixation of identities within the same ethnicity is also driven by another identity that has a huge impact on social life, that is, the identity of being a borderlander, an important aspect of identity that needs to be taken up as a separate research project. Besides the processes through which identities emerge and evolve in a community, the dynamics of borderland construction and its gradual transformation play an equal role in shaping identities. Apart from the physical political borders, the fluctuating social-boundaries that divide identities and create difference, have a complex relation with the process of 'survival' as a borderlander. This works by tapping into the inter-community engagement in micro-settings as small as a neighbourhood and analysing the intersection where religiously assertive identity within an ethnic-group produces a complex reality thereby deciding the nature of everyday socio-cultural life. Hence, this work has a scope of looking at ethnic-identities and their transformation in a newer light, especially in South-Asia, where not only the social, cultural, and political processes change them, but the geographical location of such an ethnic-community (such as a borderland with histories of partition) strongly influence identity construction and formation.

\section{Appendix 1. The Site of Ethnography: The Borderland Community of Poonch}

Poonch; a border-district on the Indian side in JammuKashmir, infamous for making headlines because of incessant cease-fire violations across the Indo-Pak border, has had a bitter past just like other regions in the area, some of which are still gasping for a breath of normalcy. However, unlike the widely known conflict-ridden Kashmir dispute, Poonch, or the similar lesser known territorial-belts of Jammu and Kashmir though have been the products of partition that rendered the state disputed and fractured in 1947-1948, such regions also have emerged as isolated pockets fighting separate struggles, ostensibly overshadowed by the gigantic discourse on Kashmir-dispute (Bouzas 2016; Lamb, 1991; Zutshi 2010). An erstwhile fief under the monarch of the princely state of Jammu and Kashmir and administered under the trustworthy kith and kin of the Maharaja of Kashmir, Poonch remained a land/territory that was situated at a certain distance from the monarchical centres in the cities of Jammu and Srinagar. However, this does not mean that it was loosely connected to the monarchy. The rajas of Kashmir held their firm grip on Poonch through the extended administration. Going back to late nineteenth and early twentieth century when the command of Poonch was taken over by the Dogra-rulers in 1840 , the raja of Poonch established this very town by bringing in skilled men and traders from outside Jammu and Kashmir apart from the locals. He incentivised them with land and service, and encouraged them to settle down 
in the otherwise dispersedly populated lands of Poonch, hence marking the beginning of the administrative centre in Poonch, (as recorded by Muhammad-ud-din Fouq in his social history, Tariq-e-aqwaam poonch, a project he completed under the patronage of the raja of poonch in 1931, making it a contested history). The grant of the Radcliffe award in 1947 that partitioned the provinces of Punjab and Bengal, also later partitioned Jammu and Kashmir as well as frontier regions like Poonch. Poonch was a fief at the western margins of the princely state of Kashmir located at a distance of 100 kilometers from one of the biggest cities of erstwhile united Punjab: Rawalpindi. In October 1947, two months into the partition of the country while the monarch of Kashmir was still deciding on whether to accede the princely state to India or to the state of Pakistan, he was shaken from his indecisiveness by a pukhtoon(pathan) tribal raid aimed at conquering Srinagar by force which was also infamous for the support and encouragement that newly formed Pakistan administration provided it (Lamb 1991; Snedden 2013). The raiders (majorly pathans from NWFP) took the route along the north-eastern regions of west-Punjab that ran parallel to Mirpur, Poonch, and Muzaffarabad of the Jammu and Kashmir State. It was under these circumstances that Jammu and Kashmir acceded to India under the widely known instrument of accession with Indian soldiers fighting this marauding army out of Jammu and Kashmir which by then had been strengthened by the reinforcements from Pakistani army (Lamb 1991; Whitehead 2007). This is also how India and Pakistan waged their first war, the war of 1947-49.

There is another important point to take into account here, which is that certain scholars like Christopher Snedden (2013) have written about the support these raiders got from people in Poonch (largely Muslims) who had been supporting the cause for an Azad Jammu and Kashmir. The men of Poonch were known to have served in British army so most of them were ex-servicemen who had rifles and other weapons. They were also frustrated under the heavy tax-regimes and other oppressive tendencies of the monarch of Jammu and Kashmir and have arisen in revolt a few times before finally supporting the raiders in their attempt at over-throwing the monarchy by violent means (Snedden, 2013). This took a flagrant communal colour as it was mostly the Muslims who took up arms and joined the raiders. The marauding raiders did not hesitate in persecuting the Hindu and Sikh Poonchies who had to run for their lives and seek shelter. Their abandoned homes across the border became part of what came to be known as the Pakistan administered territories of Azad Jammu and Kashmir, contested by India as a disputed territory. It is these Hindus and Sikhs that today form the majority refugee population on the Indian side of the town of district Poonch.

Important here is to look at the fact that these Poonchies (Hindus and Sikhs) left their homes in Poonch that now lie across the LoC in what India referes to as Pakistan Occupied Jammu and Kashmir territories and took refuge only a few miles inside the LoC in India. Another major repercussion of these events was that when the 1984 ceasefire that ended the war between India and Pakistan, it ended with a substantial modification of the geography of the erstwhile princely state. The fief was divided into two parts by the ceasefire line that, after 1972, was known as the line of control, with 855 square kilometre today lying on the other side of line of control, hence dividing the population of Poonchies into two nationalities with differing loyalties that gradually evolved as Indian and Pakistani Poonchies.

\section{Notes}

1 See Appendix 1 for more details on how the situation during 1947-48 transformed the principality of Poonch into the borderland district of Poonch.

2 For an understanding of ethnic-homelands transformed into borderlands along the line-of-control in a post-partition phase, one can refer to my work on another ethnic-group situated in a different borderland here, Nodes of Marginality: Identity, Displacement and Migration in the Post-Partition Borderlands of Kashmir, (Sharma 2021).

3 Which led to events ending in the signing of Instrument of Accession, between Maharaja Hari Singh, the Ruler of Kashmir, and India, leading to accession of Jammu and Kashmir with India.

4 The Pakistani army later took over the war officially (Lamb 1991; Whitehead 2007).

5 The district on the Indian side has an area of $1674 \mathrm{sq} . \mathrm{km}$, with a total population of 476,835 , forming $3.80 \%$ of the total population of Jammu and Kashmir State. Hindus are $5.20 \%$ of the Population, Muslims 91.93\%, Sikhs 2.76\%, and rest forming the remaining $0.37 \%$ (Census, 2011).

6 For an understanding of how these ethnicities form an outer-rim of non-dominant ethnicities along the northwestern boundary at the line-of-control see, https:// thewire.in/society/kashmiri-language-dogri-hindi-pahari

7 A sub-group of the Indo-Aryan group of languages spoken around undivided Punjab, Sindh, and the North-western Frontier Province in Pakistan today.

8 There is a fourth religious presence that has been growing within the Pahari-ethnicity here, which is the Dalit-Christians, a small minority of Dalits who have been converting to Christianity in the past few decades. My paper, In search of a religion: Making of a Dalit-Identity in Jammu and Kashmir, India (forthcoming) takes up this particular religious-caste identity in detail.

9 For a detailed account on the narratives collected see, Remaking of ethnic-boundaries: identity and religion among Sikhs in the borderland of Poonch, Jammu and Kashmir, Asian Ethnicity, (Sharma 2020)

10 The town sits on the Pir-Panjal foothills on a river bed. The Poonch river flows north-westwards into Pakistan Occupied Kashmir and the town of Poonch is situated on the northern bank of the river. The line of control divides Poonch on the north-western side, and acts as the volatile border between India and Pakistan, which is a highly disturbed zone.

11 Their accounts form the primary source of the narration included here. Though it is also important to mention that these elderly men and their accounts corroborated what oral-narratives prevalent among the middle-aged and the young were already hinting at. Hence, the account on partition is the living memory among the people here, and constitute key oral-accounts crucial for a researcher. I was lucky to have found a few persons who could still speak from their lives as and when partition in later 1940s took place and the repercussions it had on the social-cultural life of Poonchies in its immediate aftermath.

12 Please see that most of the villages falling in the border-zone of district Poonch were emptied out, as the coercion and aggression between the forces took place around the town in these village spaces (Sharma 2020). 
Borders in Globalization Review | Volume 3 | Issue 1 | Fall/Winter 2021

Sharma, "Identity, Religion and Difference in the Borderland District of Poonch, Jammu and Kashmir"

13 Paharis that assert their identity together for reservation are also found in other parts of the state. Their concentration is the highest in Poonch-Rajouri and Kishtawar, apart from Doda, Baramullah and a few other segregated clusters.

14 The Kashmiri speaking population of Poonch is restricted to a few locations and is the most widespread in Mandi Tehsil. Kashmiri here however does not denote the ethnic affiliation with Kashmiries of the valley as the Kashmirispeaking population of Poonch are the Pahari-Kashmiris that have migrated from places like Muzaffarabad and some from the valley a few centuries ago and have become assimilated with the Pahari culture such that their accent and tonality of Kashmiri language also differs from the one that is spoken in the valley. Also, Kashmiris of Mandi are one of the oldest khandans (clans) who have contributed to economy, culture and social exchange of Poonch fief, as written by Fouq in his Tariq-e-aqwaam Poonch in 1931. Fouq's was one of the earliest and perhaps the only attempt at writing a people's history of Poonch under the patronage of the Raja of Poonch.

15 See Nandy's "Time warps: Time travel to a possible self, (2002), Varshney's concept of 'networks of engagement' (2008) and Shail Mayaram's Work (1997) for an elaborate understating on this.

\section{Works Cited}

All hyperlinks last accessed December 2021 unless specified.

Aggarwal, Ravina. 2004. Beyond Lines of Control: Performing Borders in Ladakh, India. Durham, NC: Duke University Press.

Bouzas, Antia M. 2016. "The Kashmir Space: Bordering and Belonging Across the Line of Control" Revista Electronica De Estudios Internacionales. https://doi.org/10.17103/ reei.31.13

Brass, Paul. 2003. The Production of Hindu Muslim Violence in Contemporary India. New Delhi: Oxford University Press.

Choudhary, Zafar. 2011. Understanding the Gujjar Pahari Faultline in J\&K, A Gujjar Perspective. IPCS Special Report 106. IPCS Conflict Alert.

Gellner, David (ed.). 2013. Borderland Lives in Northern South Asia. Duke University Press.

Gupta, Radhika. 2013. "Allegiance and alienation: border dynamics in Kargil" in Borderland Lives in Northern South Asia, edited by David Gellner, 47-71. Duke University Press.

Lamb, Alastair. 1991. Kashmir: A Disputed Legacy 1846-1990. Oxford University Press.
Lamont, Michele, and Virag Molnar. 2002. "The Study of Boundaries in the Social Sciences" Annual Sociological Review 28: 167-195.

Mayaram, Shail. 1997. Resisting Regimes: Myth, Memory and Shaping of a Muslim Identity. Oxford University Press.

Nandy, Ashis. 2020. "The Politics of Secularism and the Recovery of Religious Tolerance" in Secularism and Its Critics, edited by Rajeev Bhargava. 321-344.

2002. Time Warps: Silent and Evasive Pasts in Indian Politics and Religion. C. Hurst and Co. Publishers.

Newman, David. 1998. "Creating the fences of territorial separation: the discourse of Israeli- Palestinian conflict resolution" Geopolitics and International Boundaries 2: 1-35.

_. 2003. "On borders and power: a theoretical framework" Journal of Borderlands Studies 18, 13-24. https://doi.org/10 .1080/08865655.2003.9695598

Newman, David, and Anssi Paasi. 1998. "Fences and neighbours in the post-modern world: boundary narratives in political geography" Progress in Human Geography 22: 186-207.

Oberoi, Harjot. 1994. The Construction of Religious Boundaries: Culture, Identity and Diversity in the Sikh Tradition. The University of Chicago Press.

Oommen, T.K. 1997. Citizenship, Nationality and Ethnicity; Reconciling Competing Identities. Cambridge Polity Press.80

Paasi, Anssi. 1998. "Boundaries as social processes: territoriality in the world of flows" Boundaries, Territory and Postmodernity. Ed. D. Newman. 69-88, London: Frank Cass.

Sharma, Malvika. 2020. "Remaking of ethnic boundaries: Identity and religion among Sikhs in the borderland of Poonch, Jammu and Kashmir" Asian Ethnicity. https://doi. org/10.1080/14631369.2020.1811951

__., 2021. "Nodes of Marginality: Identity, Displacement and Migration in the Post-Partition Borderlands of Kashmir" Journal of Immigrant and Refugee Studies. https://doi.org/ 10.1080/15562948.2021.1949656

Smith, Anthony D. 1986. Ethnic Origins of Nations. Blackwell Publishing House

Snedden, Christopher. 2013. Kashmir: The Unwritten History. HarperCollins Publishers India.

Varshney, Ashutosh. 2008. Ethnic Conflict and Civic Life: Hindus and Muslims in India. Yale University Press.

Whitehead, Andrew. 2007. A Mission in Kashmir. Penguin, New Delhi.

Zutshi, Chitralekha. 2010. "Rethinking Kashmir's history from a borderlands perspective" History Compass 8(7): 594-608. https://doi.org/10.1111/j.1478-0542.2010.00692.x 